\title{
PRICE DETERMINATION OF CHICKEN PORRIDGE SMES IN FACING RAW MATERIAL COST FLUCTUATION
}

\author{
Faizal Haris Eko Prabowo \\ Department of Management, Faculty of Economic, Universitas Galuh \\ email:faizalharisekoprabowo@gmail.com
}

\author{
Article History : \\ Received 12 October 2018 \\ Recieved in revished form \\ 24 December 2018 \\ Acepted 2 January 2019 \\ Available offline 29 January 2019 \\ Available online 31 January 2019
}

Language Transcript :

English (en)

Key Words :

Raw Material Cost Fluctuation, Price Determination,

SMEs

\begin{abstract}
The culinary industry is currently one of the best industries that are developing, this has become one of the economic supports in several regions. Based on the results of the economic census report of the Tasikmalaya City in 2016 the culinary industry in percentage and number of positions was in the third position followed by the large trade industry which occupied the first position and the processing industry in the second position. This study aims to determine the impact of changes in raw material costs lucratively on the selling pricedetermination of chicken porridge in SMEs at the City of Tasikmalaya. The population in this study were all SMEs chicken porridge entrepreneurs totaling 261 units, while the method used in this study was a survey method with a quantitative approach presented descriptively. The result of this study is that changes in raw material costs have an impact of $89.2 \%$ on the determination of the selling price of chicken porridge. In fact, this is clearly illustrated by the chicken porridge activists who prefer to set the selling price using a mixed method based on market costs and demand. This is because there is a concern from chicken porridge activists for the risks that they will get such as decreasing sales and automatically reducing their revenue streams.
\end{abstract}

\section{INTRODUCTION}

In micro-economic activities, SMEs (micro small medium sized-enterprises) are oneof the pillars that can boost the economy (Cahyadi, 2015) an area other than public consumption. At present the development of SMEs is getting better with increasing value creation(Hamali, 2013)which they created, this is due to relatively high market turmoil, especially market demand (Mulyono, 2011) more complicated. One industry that is currently increasing is the food industry or commonly called the culinary industry (Djakfar, 2015), various types of food from starting snacks, heavy foods as well as drinks now have such good added value.
For example, instant noodles commonly sold in coffee shops have now turned into one of the relatively large foods consumed in cafes with new packaging such as instant noodles with a mixture of corned beef, typical spices, etc., another example is shaved ice drinks that were previously sold by street vendors currently have small merchants with unique packaging products, namely kepal ice. Formerly surabi only has a spicy taste, original and sweet, but nowadays mozzarella, sausage, powdered milk, and jam are the choice of new flavors and there are still many examples of valueadded developed by SMEs activists.

Basically, food is a primary human need, which supports the development of 
the food SMEs industry throughout the region. Tasikmalaya is one of the cities in the province of West Java which has typical culinary namely chicken porridge, miebakso, nasitutugoncom, nasicikur, and kupattahu. Chicken porridge products are one of the products that have high demand in the culinary industry, these products are often consumed both for breakfast and dinner. Some business activists of several chicken porridge SMEs only operate in the morning, but some operate in the morning and evening to increase higher revenue streams.

On the other hand, chicken porridge SMEs sometimes experience several obstacles, one of which is the profit they get. The profit they get is not optimal, many factors cause this to happen, one of which is the cost of raw material for chicken porridge. Raw materials for chicken porridge are commodity products that have the opportunity to rise also down based on demand and supply that occur in a market. The raw material used in chicken porridge is rice, chicken meat, spices, complementary vegetables (scallions and fried onions), cakue, and crackers. The prices of these raw materials increased in certain times such as pre-Eid and post-Eid the price of raw materials increased significantly also on other days when the inventory of commodity products decreased due to the dry season which resulted in farmers failing to harvest. This is a problem for chicken porridge activists because when the price of raw materials increases there are 2 choices for them, the first decrease the portion in order to get the same profit as before or reduce the profit they get with the product benefits that do not change at all. If the entrepreneur chooses the first choice of profit they get will be stable while the benefits obtained by consumers will decrease due to the decrease in portion, the choice is always a scourge for entrepreneurs because both have different risks and benefits for both consumers and producers. Price fluctuations are difficult to predict and anticipated by all chicken porridge SMEs because demand and supply always change every month.

The full cost calculation of a product or service has a vital role in the business unit. Because this is one indicator of the sustainability of a business unit, without calculating the overall cost, the company cannot determine the selling price of the product or service optimally. The company has a purpose of maximizing profits, but many factors can reduce the profit that the company wants, one of which is the rising price of raw materials.

There have been several previous studies regarding raw material costs which have an impact on several aspects, those are (Ardianti, 2015) examine the cost of raw materials that affect the cost of production at fast food companies, (Amanah, 2017) make observations regarding raw material costs that affect product sales, (Hidayat, 2014)finding raw material costs has an impact on profit, (Tukasno, 2017)reviewing the cost of raw materials that have an impact on the volume of stove production, while (Roher, 2016) examines the cost of raw materials that affect the efficiency of production costs. Based on the first research description, this research will examine the cost of raw materials that affect the selling price of products.

In addition to previous research that discusses the cost of raw materials, there are several previous studies that examine how to determine the selling price as studied by (Nyaga \& Wilson, 2017a) Pricing can affect profitability in insurance companies, (Kireyev, Kumar, \& Ofek, 2017) investigating pricing at retailers who have offline and online marketing channels, (Liu, Zhai, \& Chen, 2018) find findings in his research regarding changes in pricing when 
companies innovate that are incremental or small,(Nyaga \& Wilson, 2017) conduct research on premium pricing on insurance companies in Kenya, (Miravete, Seim, \& Thurk, 2017) reviewing the tax policy on pricing alcohol products on different brands, (Mohebalizadeh \& Handfield, 2018) observe the changes in raw material costs that affect the cost of production, (Garner, Rintoul, \& Hill, 2018) found findings about drug pricing based on the value or efficacy of the drug not based on production costs that have been incurred, and (Na, Hwang, Hong, \& Lee, 2017) conduct a study on the efficiency of price comparison on digital content.

From several previous studies, it was found that the change in raw material costs could affect COGS, product sales, profits, and production. Whereas previous research on pricing was influenced by marketing channels, company profitability, innovation, brands, and COGS. In this study, the authors limit the research only the changes in raw material costs and pricing which are still difficult to find in some literature. Based on the background description, does the change in raw material costs have an impact on SMEs in determining the selling price of chicken porridge?

\section{THE METHOD}

In this study, the method used is a survey method with a quantitative approach presented descriptively. This method explains the effect of changes in raw material prices on the determination of the selling price of the product in a description and using simple linear regression calculations. In this study, the subject of the research was the chicken porridge SMEs in Tasikmalaya City, totaling 261 units. The amount is then sampled into 93 business units using the Slovin formula. The type of data used in this study is the primary data is nominal. The data analysis technique used in this study is simple linear regression analysis. The purpose of using the technique is to determine the impact of raw material costs on determining the selling price.

\section{RESULT AND DISCUSSION}

The impact of changes in unstable raw material costs has caused many confusing SMEs chicken porridge to determine the selling price of their products, even though they have tried to take into account all kinds of production costs, in fact, they always set their prices based on intuition. There are concerns that they are at greater risk of not selling the products they offer. If viewed empirically there are 4 methods for determining the selling price of a product or service, based on demand, cost-based, competition-based and profit-based. Each has its own characteristics and advantages. The method used by most chicken porridge SMEs is a cost-based pricing method, only what is at the core of the problem in this study is the SMEs activists mushrooming confused chicken choosing to reduce the portion or increase the selling price.

In this study, a quantitative approach is used to explain how much the impact of changes in raw material costs on price fixing using simple linear regression techniques. To calculate the effect, primary data changes the raw material costs and selling prices for each month in a year. The data on raw material costs and selling prices are as follows: in January the cost of raw materials at a price of Rp. 6,000, while the selling price is Rp. 8,000, there is a decrease in raw material costs of $-3.33 \%$ to Rp. February, in the following month March there was an increase in raw material costs by $6.45 \%$ to $\mathrm{Rp} 6,200$ but with the selling price still unchanged, in April there 
was a decrease of $-3.22 \%$ of the cost of raw materials to $\mathrm{Rp} 6,000$ while the selling price remained the same as January. In the following month, there were no changes in both raw material costs and selling prices. Furthermore, in June there was an increase of $20 \%$ in raw material costs which forced these MSMEs to increase their selling prices by $12.5 \%$ from the previous price to Rp. 9,000. Not there, the following month raw materials increased by $18 \%$ from the price in the previous month to $\mathrm{Rp} .8,500$ and sold at Rp. 10,000, an increase of $11.1 \%$ from the selling price last month. In August, the raw material costs decreased by $-7 \%$ and the selling price declined again by $10 \%$. But in the next four months there was no change in selling prices until the end of the year there was only a change in raw material costs in the next four months as in September decreased by $-6.32 \%$, October decreased by $-5.4 \%$, then in November increased again at $2.85 \%$ and at the end of the year declined to Rp. 6,800 or $5.55 \%$, while the selling price remained stable in the last four months at Rp. 9,000.

The data explained that almost every month there were fluctuations in raw material prices even during certain months the price changed drastically to almost two times the normal price. When the price of raw materials increased, the cost of production of chicken porridge increased as well as the selling price of chicken porridge. However, where there are a decrease and an increase in raw material costs that are not too sharp, chicken porridge SMEs does not act to change the selling price. From the results of the calculation of data analysis using simple linear regression found that changes in raw material costs have an impact on the selling price of chicken porridge is very strong. The impact of the change in costs was $89.2 \%$. The results of these calculations explain that the pricing strategy with any method is still influenced by the cost of raw materials used to produce chicken porridge.

\section{CONCLUSION}

Based on the results of the analysis and discussion in this study, it can be concluded that changes in raw material costs have an effect of $89.2 \%$ on the determination of the selling price of chicken porridge. This role is in a very strong category, this is a determining factor in the selling price of chicken porridge. Therefore when changes in raw material costs occur, chicken porridge SMEs is always confused in making decisions to increase or decrease the selling price. The use of any pricing method initially still refers to the cost of production. In the end, SMEs activists porridge preferred to reduce their profits rather than have to increase the selling price. They are worried that the rise in both good and low prices will have a high impact on the psychological of consumers, which in turn will appear to threaten the lack of revenue streams they will get from the sale of chicken porridge. In the end, the method they use in setting the selling price of chicken porridge is a mixed method that is calculated based on the cost and market demand.

\section{REFERENCE}

Amanah, S. (2017). Jurnal Analisis Pengaruh Biaya Bahan Baku, Biaya Tenaga Kerja Langsung Dan Biaya Overhead Pabrik Terhadap Penjualan Produk di Cv Surya Pustaka Analysis Ot the Effect of Raw Material Cost , Direct Labor Cost and Factory Overhead Cost on the Sale of Produc. Simki-Economic, 01(02).

Ardianti, Y. (2015). Overhead Pabrik Terhadap Harga Pokok Produksi Pada. Jurnal Jurusan Pendidikan Ekonomi (JJPE), 5(1).

Cahyadi, I. (2015). 29 Tantangan Internasionalisasi Ukm Di Indonesia Dalam Menghadapi Masyarakat 
Ekonomi Asean Challenges of Internationalization of Indonesia'S Smes Towards Asean Economic Integration, 27(9), 129-144.

Djakfar, M. (2015). Makna Kerja Bagi Pengusaha Kecil Muslim Di Tengah Perkembangan Bisnis Kuliner. https://doi.org/10.19105/ihkam.v10i2.7 36

Garner, S., Rintoul, A., \& Hill, S. R. (2018). Value-Based Pricing: L'Enfant Terrible? PharmacoEconomics, 36(1), 5-6. https://doi.org/10.1007/s40273017-0567-4

Hamali, S. (2013). Meningkatkan Inovasi Melalui Entrepreneurial Marketing Dan Dampak Pada Kinerja Pemasaran Ukm- Ukm Garment Di Jawa Barat. JP.Feb.Unsoed - Journal \& Proceeding, 3(1).

Hidayat, S. (2014). Analisis Pengaruh Biaya Bahan Baku Dan Biaya Tenaga Kerja Langsung Terhadap Laba Usaha Pada Texas Collection.

Kireyev, P., Kumar, V., \& Ofek, E. (2017). Match Your Own Price? SelfMatching as a Retailer's Multichannel Pricing Strategy. Marketing Science, 36(6), 908-930. https://doi.org/10.1287/mksc.2017.103 5

Liu, J., Zhai, X., \& Chen, L. (2018). Optimal pricing strategy under trade-in program in the presence of strategic consumers. Omega, 1-17.

Miravete, E. J., Seim, K., \& Thurk, J. (2017). One Markup to Rule Them All: Taxation by Liquor Pricing Regulation. NBER Working Paper. Retrieved from http://conference.nber.org/confer/2017/ SI2017/IO/Thurk_Seim_Miravete.pdf

Moheb-alizadeh, H., \& Handfield, R. (2018). The Impact of Raw Materials Price Volatility on Cost of Goods Sold (COGS) for Product Manufacturing.

Mulyono, F. (2011). Demand Chain Management : Supply Chain Management + Orientasi Pasar, 7(1), 63-76.

Na, H. S., Hwang, J., Hong, J. Y. J., \& Lee, D. (2017). Efficiency comparison of digital content providers with different pricing strategies. Telematics and Informatics, 34(2), 657-663. https://doi.org/10.1016/j.tele.2016.10.0 06

Nyaga, P. K., \& Wilson, M. (2017a). AN Analysis Of The Effect Of Pricing Strategies On Profitability Of Insurance Firms In Kenya International Journal of Finance And Accounting An Analysis Of The Effect Of Pricing Strategies. International Journal of Finance and Accounting (IJFA), 2(6), 79-92.

Nyaga, P. K., \& Wilson, M. (2017b). An Analysis Of The Effect Of Pricing Strategies On Profitability Of Insurance Firms In Kenya International Journal of Finance And Accounting An Analysis Of The Effect Of Pricing Strategies. International Journal of Finance and Accounting, 2(7), 107118.

Roher, T. D. N. (2016). Pengaruh Biaya Bahan Baku Dan Biaya Tenaga Kerja Langsung Terhadap Efesiensi Biaya Produksi Pada Perusahaan Pt. Anggrek Hitam Dengan Periode Tahun 2013-2015.

Tukasno. (2017). Pengaruh Biaya Bahan Baku Dan Biaya Tenaga Kerja Terhadap Volume Produksi Tungku Di Desa Braja Mulya Kecamatan Braja Selebah, 3(2), 25-36. 